The Ninety-fifth Meeting of The Nutrition Society was held at The Medical College of St Bartholomew's Hospital, London, E.C. I, on Saturday, 7 May 1955, at 10.30 a.m., when the following papers were read:

The Vitamin D Content of Tissues of Rats Irradiated with Ultraviolet Light. By Ethel M. Cruickshank and E. KodiceK, Dunn Nutritional Laboratory, University of Cambridge and Medical Research Council and P. ARMITAGE, Statistical Research Unit of the Medical Research Council, London School of Hygiene and Tropical Medicine, University of London

It has been known for the past four decades that rickets in man and animals can be cured by ultraviolet irradiation, and it is accepted that the curative effects are due to the conversion to vitamin $\mathrm{D}$ of 7 -dehydrocholesterol in the superficial layers of the epidermis (Bachem, I930). Since there appears to be no information as to how much vitamin $\mathrm{D}$ is formed in this process, experiments were undertaken to ascertain, biologically, by the method of Bourdillon, Bruce, Fischmann \& Webster (I93I), the vitamin D content of skin and livers of rachitic rats subjected to u.v. irradiation, until rickets, judged radiographically, was almost healed. To find to what extent the presence of fur impaired the penetration of u.v. rays, rats from which the dorsal fur had been removed were similarly irradiated. In control rachitic rats, which had been irradiated with infrared light, no vitamin D was detected in skin or liver. The skin of animals irradiated with u.v. light contained 5 i.u./g, which represented 66 i.u./rat. The liver, which is the main storage organ, contained 2 i.u./g, or 8 i.u. per whole liver. A certain amount of the newly formed vitamin was therefore being distributed throughout the body. In animals from which the dorsal fur had been removed before irradiation, considerably more of the vitamin was found in the skin $(22 \mathrm{i} . \mathrm{u} . / \mathrm{g}$ or $290 \mathrm{i} . \mathrm{u} . / \mathrm{rat})$. The vitamin content of the liver increased slightly, to 3.7 i.u./g or I 5 i.u. per whole liver. The presence of fur, therefore, greatly impaired the penetration of u.v. light.

When squares of dorsal skin, removed from rachitic rats, were irradiated, larger amounts of the vitamin, $\mathbf{I}_{3} \mathrm{i}$.u./g, were formed. A fourfold increase was found when isolated skin was irradiated after removal of the fur. In fur irradiated after removal from rachitic rats, or in fur from irradiated animals, no vitamin $D$ could be detected. This observation does not confirm the suggestion of Lucas (I933) that the formation of vitamin $D$ is dependent on the blood supply.

The fact that the fur of irradiated rats and isolated irradiated fur contained no vitamin $\mathrm{D}$ suggests that the vitamin is transferred directly from the skin to other parts of the body and moreover, that, in the rat, the skin secretions have no precursors of the vitamin, an observation which applies also to human sebum (MacKenna, Wheatley \& Wormall, 1952). 
Bachem, A. (1930). Amer. F. Physiol. 91, 58.

Bourdillon, R. B., Bruce, H. M., Fischmann, C. \& Webster, T. A. (193I). Spec. Rep. Ser, med. Res. Coun., Lond., no. 158.

Lucas, N. S. (1933). Biochem. F. 27, I32.

MacKenna, R. M. B., Wheatley, V. R. \& Wormall, A. (1952). Biochem. F. 52, I6r.

Cortisone and Vitamin $\mathrm{C}$ Requirements. An Assessment by the Toothstructure Method. By L. J. Harris, B. J. Constable, R. E. Hughes and G. LoEwI, Dunn Nutritional Laboratory, University of Cambridge and Medical Research Council

Groups of guinea-pigs were given graded doses of ascorbic acid; their degree of protection from deficiency was assessed by the dental-histology method; and the corresponding dose-response curve was constructed. A second set of guinea-pigs received identical treatments except that, in addition to the graded doses of vitamin $\mathrm{C}$, daily injections of cortisone $(7.5 \mathrm{mg})$ were also administered. No appreciable difference was found in the resulting dose-response curves, as between the animals receiving cortisone and those not receiving it, although it was shown that the cortisone had the effect of diminishing the relative concentration of ascorbic acid in the adrenal glands, in the groups on the lower intakes of the vitamin. It is concluded therefore that, contrary to some earlier supposition in the literature, cortisone did not influence the overall requirements for vitamin $\mathrm{C}$.

\section{Effect of Continued Administration of Cortisone and ACTH on Vitamin C} Levels in Guinea-pig Adrenals. By B. J. Constable, L. J. Harris and R. E. Hughes, Dunn Nutritional Laboratory, University of Cambridge and Medical Research Council

In guinea-pigs maintained on various graded intakes of vitamin $\mathrm{C}$, the continued administration of cortisone (e.g. 7.5 or $15 \mathrm{mg} /$ day, injected for Io days) led to a notable fall in the concentration of ascorbic acid in the adrenal glands. Since the hormone causes diminution in adrenal weight, the effect was even greater when expressed in terms of the total amount of ascorbic acid present in the glands.

ACTH (8 mg Armour standard L.A.r.A. (The Armour Laboratories, Chicago) per day for Io days) had a similar action in diminishing the concentration of ascorbic acid, but, since the glands were greatly enlarged, the total quantity present was raised.

Autoradiographic Demonstration of Variation in Uptake of ${ }^{35} \mathrm{~S}$ by Scorbutic Guinea-pigs. By C. RUTH Hill and G. H. Bourne, Department of Histology, London Hospital Medical College, London, E.I

Friberg \& Ringertz (1954), using the Geiger counter, have shown that the uptake of ${ }^{35} \mathrm{~S}$-labelled sodium sulphate by various tissues and organs of scorbutic guineapigs is only about one-third that of normal guinea-pigs' tissues. Using biochemical 
methods and the Geiger counter, Dziewiatowski (1949) has shown that ${ }^{35} \mathrm{~S}-$ labelled sodium sulphate when injected intraperitoneally into rats, is incorporated chiefly into the chondroitin sulphate of cartilage, and by similar methods Reddi \& Nörstrom (1954) have shown that the incorporation of ${ }^{35} \mathrm{~S}$ into chondroitin sulphate of scorbutic costal cartilage is only about one-third that of normal costal cartilage. We have investigated the uptake of ${ }^{35} \mathrm{~S}$ in various tissues and organs of normal and scorbutic guinea-pigs by autoradiographic techniques, in order to confirm if possible the biochemical findings and to discover the site of variation in uptake of the isotope in the different organs.

Pair-fed guinea-pigs of 200-250 $\mathrm{g}$ were fed on rat-cake supplemented with vitamins $A$ and $D$, and in the case of control animals with ro $\mathrm{mg}$ vitamin $\mathrm{C}$ daily. After about 3 weeks all animals were given an intraperitoneal injection of $5 \mu \mathrm{c} / \mathrm{g}$ body-weight of ${ }^{35} \mathrm{~S}$-labelled sodium sulphate in $0.9 \%$ saline with $0.02 \%$ sodium sulphate as carrier. They were killed about $6 \mathrm{~h}$ after injection, pieces of tissue were removed, fixed in absolute alcohol, dehydrated and embedded and Io $\mu$ sections were cut in the usual way. Both contact and stripping film autoradiographic methods were used and the slides were exposed for various lengths of time. After development the tissues were sometimes stained lightly with celestin blue.

Examination of costochondral junction, knee joint, digit, nasal cartilages, lung and trachea, revealed that in scorbutic cartilage there was either a general decreased uptake of ${ }^{35} \mathrm{~S}$, or else the activity though giving a strong autoradiograph, was confined mainly to the cells of the cartilage. This was in contrast to the normal cartilage where activity occurred in both cells and intercellular ground substance. These observations are of interest in view of the fact that in scurvy the synthesis of ground-substance material by certain cells is believed to be inhibited and perhaps abnormal products are formed which cannot be converted into the necessary intercellular material. Subepithelial connective tissue of scorbutic skin and seminal vesicles showed a reduced uptake of ${ }^{35} \mathrm{~S}$. Other soft tissues showed slight or no variations. These included striated muscle, eye, testis, salivary gland, small and large intestine, liver, cerebrum and cerebellum.

\section{REFERENCES}

Dziewiatowski, D. D. (1949). F. biol. Chem. 178, 197.

Friberg, U. \& Ringertz, N. R. (1954). Exp. Cell Res. 6, 527.

Reddi, K. K. \& Nörstrom, A. (1954). Nature, Lond., r73, 1232.

Histochemical Dephosphorylation of certain Vitamin Phosphates. By G. H. Bourne, Department of Histology, London Hospital Medical College, London, E. I

Histochemical studies have been made of the ability of acetone-fixed tissues of the rat to dephosphorylate certain vitamin phosphates at $\mathrm{pH} 9 \cdot 0$. These were the sodium salt of riboflavin 5 -phosphate (flavin mononucleotide), pyridoxal phosphate (codecarboxylase), tetrasodium-2-methyl-I :4-naphthohydroquinone diphosphate 
and the sodium salt of tocopheryl phosphate. The distribution of the histochemical reaction obtained using each of these substances as substrates was compared with that obtained using sodium $\beta$-glycerophosphate. This latter substance is said to be split by non-specific alkaline phosphatase.

It was found that under the conditions of these experiments tocopheryl phosphate did not appear to be hydrolysed, while the naphthohydroquinone phosphate was dephosphorylated in a manner identical with glycerophosphate.

Profound differences in distribution of the dephosphorylating activity of various tissues were obtained with the riboflavin and pyridoxal phosphates in the case of some organs.

With both these substrates many of the cells in both cerebrum and cerebellum gave a positive reaction. In some cells the reaction is mainly in the nuclei. With glycerophosphate a positive reaction is given in the brain only by the capillary vessels. Striking differences were also found in the adrenal. With glycerophosphate the rat adrenal gives a positive reaction only in the sinusoids of the cortex. With riboflavin phosphate there is positive nuclear reaction and a slight cytoplasmic and mitochondrial reaction in the cortical cells. With pyridoxal phosphate the cortical cells showed a strongly positive cytoplasm together with a positive nucleus. In the heart glycerophosphate showed a positive reaction only in the capillaries and in the intercalated discs of the heart-muscle fibres, a reaction which was duplicated (although the capillary reaction was much less) with riboflavin phosphate. Pyridoxal phosphate, however, resulted in a strong positive reaction by the sarcosomes and the intercalated discs were negative. In the kidney and the gut the reactions with riboflavin and pyridoxal phosphate differed from that obtained with glycerophosphate mainly in demonstrating a positive reaction in the nuclei.

It is possible that sites of dephosphorylation of riboflavin and pyridoxal phosphates may also be sites of phosphorylation.

Palm Wine in Human Nutrition. By C. R. C. Heard (introduced by B. S. PlatT), Department of Botany, University of Natal, and Human Nutrition Research Unit, Medical Research Council Laboratories, Holly Hill, London, N.W.3

Palm-wine making in Tongaland, S.E. Africa, has previously been described (Junod, 1927; Heard, 1949). The results of a study of yeast proliferation, acid production by bacteria, and the nicotinic acid and riboflavin contained in Tongaland palm wine are given in the table, together with data from other sources.

The nutritive value of palm wine depends on the sugar content of the sap, the period of fermentation and the extent to which the nutrients are contained in living yeast (Leong, 1953). Not only may its contents be unavailable to the consumer but living yeast may induce a deficiency in the presence of an otherwise adequate diet (Ness, Price \& Parsons, 1946). Beriberi has been reported in palm tappers (Walters \& Smith, 1952). This is regarded as an occupational disease resulting from 


\begin{tabular}{|c|c|c|c|c|c|c|}
\hline \multirow[b]{2}{*}{ Component } & \multicolumn{5}{|c|}{ Stage in fermentation } & \multirow{2}{*}{$\begin{array}{l}\text { Percentage } \\
\text { in fluid } \\
\frac{1}{2}-1 \text { day } \\
\text { old } \\
\text { (Leong, 1953) }\end{array}$} \\
\hline & Fresh & $\begin{array}{c}\frac{1}{2}-\mathrm{I} \text { day } \\
\text { (Leong, } \\
\text { I953) }\end{array}$ & $\begin{array}{c}\text { I-2 days } \\
\text { (Heard, } \\
\text { I949) }\end{array}$ & $\begin{array}{c}2-4 \text { days } \\
\text { (Heard, } \\
\text { r949) }\end{array}$ & $\begin{array}{c}7 \text { days } \\
\text { (Dalziel, } \\
\text { 1937) }\end{array}$ & \\
\hline Yeast cells $(\%(v / v))$ & & 2 & 3 & 3 & & \\
\hline Crude protein $(\mathrm{g} / \mathrm{L}$ ) & & 2 & 4 & 4 & & \\
\hline Total sugars (g/l.) & $\begin{array}{l}\text { I70 } \\
\text { kill, } 193\end{array}$ & 31 & & & & \\
\hline Alcohol $(\%(v / v))$ & & 5 & & & $2-5$ & \\
\hline Acid (m-equiv/l.) & & 70 & $\mathrm{II2}$ & 293 & & \\
\hline Iron (mg/l.) & & $3 \cdot 2$ & & & & 70 \\
\hline Thiamine (mg/l.) & & 0.24 & & & & $1 \cdot 3$ \\
\hline Riboflavin (mg/l.) & & $0.1 \mathrm{I}$ & 0.24 & & & 25 \\
\hline $\begin{array}{l}\text { Nicotinic acid (mg/l.) } \\
\text { Ascorbic acid }(\mathrm{mg} / \mathrm{l} .)\end{array}$ & $145^{\circ}$ & $3 \cdot 7$ & 4.0 & & & 59 \\
\hline
\end{tabular}

drinking about 9 pt. of unfermented sugary sap daily (Fox, 1955). No cases of deficiency disease attributable to palm wine have been reported among people drinking only the fermented sap. Judgment of the nutritive value of an indigenous fermented drink like palm wine depends on assessing its chemical and biological composition against a background knowledge of the rest of the diet, of the implications of its possible misuse as an alcoholic beverage and of its traditional function in the social life of the people (Platt, 1955).

\section{REFERENCES}

Bergouniou, J. L. (I95I). Problème Alimentaire et Nutritionnel. Dakar: Mission Anthropologique de l'A.O.F.

Burkill, 1. H. (1935a). A Dictionary of the Economic Products of the Malay Peninsula. Vol. I. p. 6ro. London: Crown Agents for the Colonies.

Burkill, I. H. (1935b). A Dictionary of the Economic Products of the Malay Peninsula. Vol. 2, p. $155^{8}$. London: Crown Agents for the Colonies.

Dalziel, J. M. (1937). The Useful Plants of West Tropical Africa. p. 5o6. London: Crown Agents for the Colonies.

Fox, R. H. (1955). Personal communication.

Junod, H. A. (1927). The Life of a South African Tribe, and ed. Vol. 2, p. 42. London: Macmillan \& Co. Ltd.

Heard, C. R. C. (1949). Bull. Natal Soc. Pres. Wild Life. October to February, p. 4.

Leong, P. C. (1953). Brit. F. Nutr. 7, 253.

Ness, H. T., Price, E. L. \& Parsons, H. T. (1946). Science, ro3, 198.

Platt, B. S. (1955). Proc. Nutr. Soc. 14, I 15.

Walters, J. H. \& Smith, D. A. (1952). W. Afr. med. F. N.S. I, I.

Some Nutrients of the Plantain (Musa paradisiaca) and its Relation to Protein Malnutrition. By F. E. Byron (introduced by B. S. PlatT), Applied Nutrition Unit, London School of Hygiene and Tropical Medicine

In parts of Africa the plantain forms the main portion of the diet, in some cases as much as $6 \mathrm{lb}$./ head being consumed daily (East Africa High Commission, 1952). There is increasing evidence that a low-protein, high-carbohydrate diet produces many of the clinical signs seen in the disease called kwashiorkor. A prominent feature of the disease is a fatty liver so that shortage of lipotropic factors, other than those 
due to protein deficiency, has been suspected. It should be appreciated that, apart from a paper by Raymond (1940), there is very little detailed published information on the chemical composition and nutritive value of the plantain; with this in mind, some data have been obtained on the nitrogen, methionine, choline and inositol content of the plantain.

The material used was the cooked plantain (cooked by boiling in water), as this is the form in which it is most generally eaten; the analytical results are given here:

$\begin{array}{lccr}\text { Moisture } & 74.9 \% & \text { Choline } & 0.42 \mathrm{mg} / \mathrm{I00} \mathrm{g} \\ \text { Nitrogen } & 0.23 \% & \text { Inositol } & 45 \mathrm{mg} / \mathrm{I00 \textrm {g }} \\ \text { Methionine } & 12 \mathrm{mg} / \mathrm{ro0 \textrm {g }} & & \end{array}$

Choline was determined by the method of Ramsay \& Stuart (194r) and inositol by the method of Platt \& Glock (1943). Methionine was determined by paper chromatography and the result is probably accurate to $\pm 10 \%$. Converted to $\mathrm{g} / \mathrm{I} 6 \mathrm{~g}$ nitrogen ( $100 \mathrm{~g}$ protein) the methionine figure $(0.84 \mathrm{~g}$ methionine/100 $\mathrm{g}$ protein) is not exceptionally low for a vegetable protein. The limiting factor in the diet is presumably the low protein content. A young child eating $1000 \mathrm{~g}$ plantain (970 Cal.) would receive only $14 \mathrm{~g}$ protein from this source. Where plantain forms the bulk of the diet, the amount of protein from other sources is likely to be very small and the ratio of carbohydrate to protein is high. The effect of a low-protein, highcarbohydrate diet on the livers of growing rats has been described by Lindan (I954).

\section{REFERENCES}

East Africa High Commission (I952). [Bukoba Report] East Africa Medical Survey Annual Report I952, p. 50.

Lindan, O. (1954). In Malnutrition in African Mothers, Infants and Young Children. London: H.M. Stationery Office.

Platt, B. S. \& Glock, G. E. (1943). Biochem. F. 37, 709.

Ramsay, W. N. M. \& Stewart, C. P. (I94I). Biochem. F. 35, 39.

Raymond, W. D. (1940). E. Afr. agric. F. 6, I05.

The Relation between Protein Efficiency and Net-protein Utilization. By A. E. Bender, Bovril Ltd, I48 Old Street, London, E.C.I

Protein-efficiency ratio is the simplest method of assessing protein quality, but has serious limitations. One drawback is that variations in food intake affect the result. The more complex measure, net-protein utilization, is not affected by food intake.

Roller-dried skim milk was assayed six times by the simplified method of Bender \& Miller (1952); the N.P.U.'s were 64, 63, 64, 61, 64 and 63. The P.E.'s measured in the same experiment were $2 \cdot 47,2 \cdot 68,2 \cdot 77,2 \cdot 76,1 \cdot 70$ and $1 \cdot 29$ respectively. In all cases the feeding was ad lib., but consumption varied from one experiment to another. P.E. correlated with food intake/ $100 \mathrm{~g}$ body-weight, $r=0.915$ ( $P>0.0 \mathrm{r})$ : (when the food intake was calculated as intake/ $\mathrm{W}^{0 \cdot 88}$, the correlation was lower, 
$r=0.838$ ). Similarly, bread fortified with lysine was assayed four times: P.E.'s were $0.2,0.9, \mathrm{I} \cdot 8$, and 2.3 and correlated $r=0.958$ with food consumption.

Among the many factors affecting food intake is the quality of the protein in the diet. With sixteen proteins, varying in N.P.U. from 19 to 93 , food intake (per roo $g$ body-weight) correlated with N.P.U., $r=0.85 \mathrm{I}, y$ (N.P.U.) $=0.74 x-27 \cdot 3$. (The correlation was slightly lower, $r=0.839$, when food consumption was calculated as food $\left./ \mathrm{W}^{\mathbf{0}}{ }^{\mathrm{B} 8}\right)$. As P.E. rises with food intake, this means that proteins of higher quality have exaggerated values and those of lower quality depressed values.

With this serious drawback, it is surprising that a close correlation was found by Block \& Mitchell (1946-7) between P.E. and N.P.U. $\left(r=0.83_{3} 8, y\right.$ (N.P.U.) $=$ $37 \cdot 2+14 \cdot 05 x)$. It has been confirmed on thirteen proteins assayed for both N.P.U. and P.E. in the same experiments on the same groups of rats. The correlation coefficient was $0.9 \mathrm{I} 2(P>0.00 \mathrm{I})$ and the regression equation $y=30+14.5 x$. The difference between these two regressions is very small in view of the fact that in the first-mentioned regression practically every value was measured in a different laboratory.

The figures indicate that when N.P.U. is less than 30 animals are unable to grow and therefore P.E. cannot be measured. It should be possible, however, to determine negative P.E.'s. The regression between P.E. and N.P.U. for ten proteins with N.P.U. less than 50 (i.e. P.E. very small or negative) was $y=39+9 x(r=0.797)$ in contrast to those of higher N.P.U. This change in slope is apparently due to the reduced consumption of proteins of low quality, of which the P.E.'s are consequently underestimated.

\section{REFERENCES}

Bender, A. E. \& Miller, D. S. (1952). Biochem. Y. 53, vii. Block, R. J. \& Mitchell, H. H. (1946-7). Nutr. Abstr. Rev. 16, 249.

\section{The Availability to Animals of Vitamin $B_{12}$ Bound with Their Own or} with Foreign Binding Factors. By Marie E. Coates, Margaret E. Gregory, G. F. Harrison, Kathleen M. Henry, E. S. Holdsworth and S. K. KoN, National Institute for Research in Dairying, University of Reading

In the various tissues and secretions we have tested, e.g. the gastro-intestinal tract, liver, serum and milk, vitamin $B_{12}$ occurs in combined form and there is usually an excess of the binding substance. Gregory \& Holdsworth (1955) have shown that the ability to 'bind' vitamin $B_{12}$ is not a general property of proteins but is due to specific substances. We have tested the availability of the various bound forms by giving them to vitamin $\mathrm{B}_{12}$-deficient chicks and rats. For the chicks, the bound form was mixed with the deficient diet; it was given to rats separately each day.

A commercial preparation of dried pig stomach (Extomak, Bengers Ltd, Holmes Chapel, Cheshire), and a concentrate of the binding material therefrom, made 
vitamin $\mathrm{B}_{12}$ less available than the free vitamin for chicks and rats (Anonymous, 1953). These findings are in agreement with those of Rosenblum, Woodbury, Gilfillan \& Emerson (1954), who reported that intrinsic-factor concentrates from pig gastric mucosa rendered vitamin $B_{12}$ less available to the rat.

A cyanocobalamin-protein complex prepared from an extract of pig-pylorus mucosa (G.E.A., Copenhagen) had only a fraction of the activity of free vitamin $B_{12}$ when given by mouth to chicks or rats, but had full activity when administered parenterally. Sow's milk, which is the sole source of the vitamin for the suckling pig, also had the property of rendering vitamin $B_{12}$ less available to the chick, but the complex was fully available to the rat.

To test whether the binding substance was specific for different species, various homologous and heterologous bound forms were prepared for testing with chicks and rats. In all tests so far, all the bound forms were fully active when injected. Vitamin $B_{12}$ bound by extracts of chick proventriculus was fully active by mouth for both chicks and rats. This finding rules out a straightforward species specificity. It is interesting that for the chick vitamin $B_{\mathbf{1 2}}$ bound by rat-stomach extract had only about a quarter of the activity of the free vitamin, whereas it was fully available to the rat. The investigation is being extended to other species, but the preliminary findings show that the availability of bound vitamin $B_{12}$ given by mouth depends greatly on the origin of the binding material.

\section{REFERENCES}

Anonymous (1953). Rep, nat. Inst. Dairy., Reading, p. 93.

Gregory, M. E. \& Holdsworth, E. S. (1955). Biochem. $\mathcal{F . ~ 5 9 , ~} 329$.

Rosenblum, C., Woodbury, D. T., Gilfillan, E. W. \& Emerson, G. A. (1954). Proc. Soc. exp. Biol., N.Y., 87, 268.

\section{Calorimetric Measurements of the Nutritive Value for Sheep of Dried Grass Prepared in Different Ways. By K. L. Blaxter and N. McC. Graham, Hannah Dairy Research Institute, Kirkhill, Ayr}

Determinations of carbon, nitrogen and energy retention were made with six sheep given the same sample of artificially dried grass prepared in three different ways-as chaff or as two types of cubes-and at two levels of feeding. One batch of cubes ('medium cubes') was made following hammer milling and the grass for the other ('fine cubes') was milled twice using a $\frac{1}{16}$ in. screen before cubing. Each of eighteen experiments lasted $2 \mathrm{I}$ days, calorimetric observations being limited to the last 6 days. Twelve determinations of the fasting katabolism were made also.

The mean results are given in the table, and show that with cubes the sheep lost more energy in the faeces and less as methane than they did with chaff. Urinary losses were not significantly affected. Consequently, the energy digested and metabolizable was markedly superior for the chaff, particularly at the higher level of feeding. The loss of energy as heat by the sheep given chaff was, however, much greater 
Energy losses, metabolizable energy and net energy expressed as Cal./100 Cal. gross energy ingested by sheep

(Means of three animals)

\section{Level of feeding}

High

$\begin{array}{ll} & \text { Lost in faeces } \\ \text { Lost in urine } \\ \text { Lost in methane } \\ \text { Lost in heat } \dagger \\ \text { Metabolizable } \\ \text { Net } \$\end{array}$

$$
\text { Energy }
$$

Lost in faeces

Lost in urine

Lost in methane

Lost in heat $\dagger$

Metabolizablet

Net§

Net $\S$

\begin{tabular}{|c|c|c|c|}
\hline \multicolumn{3}{|c|}{ Mode of preparation of grass } & \multirow{2}{*}{$\begin{array}{c}\text { Standard } \\
\text { error of } \\
\text { means }\end{array}$} \\
\hline Chaff & $\begin{array}{c}\text { 'Medium' } \\
\text { cubes }\end{array}$ & $\begin{array}{l}\text { 'Fine' } \\
\text { cubes }\end{array}$ & \\
\hline $26 \cdot 8$ & $34 \cdot 8$ & $37 \cdot 9$ & $\pm \mathbf{I} \cdot \mathbf{I} 3^{* *}$ \\
\hline $\begin{array}{l}5 \cdot 17 \\
7 \cdot 61\end{array}$ & $\begin{array}{l}4.90 \\
5.87\end{array}$ & $\begin{array}{l}4 \cdot 77 \\
4 \cdot 61\end{array}$ & $\begin{array}{l} \pm 0.40 \text { N.S. } \\
\pm 0.25^{* *}\end{array}$ \\
\hline 28.8 & $2 I \cdot 2$ & $21 \cdot 9$ & $\pm 0.53^{* *}$ \\
\hline 60.4 & $54 \cdot 4$ & $53 \cdot 2$ & $\pm 1.02 * *$ \\
\hline $3 I \cdot 6$ & $33 \cdot 2$ & $3 I \cdot 3$ & \pm 0.97 N.S. \\
\hline 23.3 & $29 \cdot 6$ & $28 \cdot I$ & $\pm I \cdot 13^{*}$ \\
\hline $\begin{array}{l}5.06 \\
8.25\end{array}$ & $\begin{array}{l}4 \cdot 22 \\
7 \cdot 38\end{array}$ & $\begin{array}{l}4 \cdot 70 \\
7 \cdot 84\end{array}$ & $\begin{array}{l} \pm 0.40 \text { N.S. } \\
\pm 0.25 \text { N.S. }\end{array}$ \\
\hline 17.8 & 13.5 & 13.4 & $\pm 0.53^{*}$ \\
\hline 63.4 & 58.8 & $59 \cdot 3$ & $\pm 1.02^{*}$ \\
\hline $45 \cdot 6$ & $45 \cdot 3$ & $46 \cdot 0$ & \pm 0.97 N.S. \\
\hline
\end{tabular}

* Statistically significant when $0.05>P>0.01$. ** Statistically significant when $P<0.01$. N.S. Not statistically significant.

† Using the heat production of fast as the base-line. $\ddagger$ Uncorrected to $\mathrm{N}$ equilibrium. $\S \mathrm{The}$ integral net energy of Blaxter \& Graham (1955).

than by those given cubes. The net energy of the three materials was identical, that is their true nutritive value did not reflect the differences in their metabolizability. The lower net energy at high planes of nutrition is in accordance with our previous findings (Blaxter \& Graham, I954, I955), and the errors attached to the net energy values are much lower than those which can be calculated to have existed in older Continental and American work in this field.

\section{REFERENCES}

Blaxter, K. L. \& Graham, N. McC. (1954). Proc. Nutr. Soc. 13, vii. Blaxter, K. L. \& Graham, N. McC. (1955). F. agric. Sci. (In the Press.)

Food Intakes and Faecal Excretions of Two Men while Sledging in North Greenland. By J. P. Masterton and H. E. Lewis, National Institute for Medical Research, Holly Hill, London, N.W.3, and Elsie M. WidDowson, Medical Research Council Department of Experimental Medicine, University of Cambridge

This investigation was prompted by the observation that husky dogs voraciously eat human faeces. The dogs accompanying the British North Greenland Expedition were fed on dried fish and kitchen scraps while at the base camp, and they had about $2 \mathrm{lb}$. of dog pemmican a day while on trail. It is possible that they were chronically deficient in one or other of the B-vitamins but, from the data that are available on the B-vitamin content of foods of the type the dogs were eating, this seems 
unlikely. Another suggestion that has been made is that persons living on the highfat polar rations might pass fatty stools. In order to test this second possibility, two men recorded the amounts of food they ate during a spring sledging trip in North Greenland; they also collected their faeces over a period of 14 days and brought them back to England for analysis. The calorie intakes were about $4{ }^{1} 5^{\circ} \mathrm{Cal}$. and the fat intakes $270 \mathrm{~g}$ a day. The men absorbed $97 \%$ of this fat, and their faeces were normal in composition and contained no excess of fat. There must be some other explanation, therefore, for the coprophagic habits of the dogs.

Some Effects of Thiamine Deprivation and Caloric Deficiency in the Rat on Learning and on Behaviour under Stress. By F. KNOPFELMACHER, Melek Khairy and R. W. Russell, Department of Psychology, University College, London, and John Yudkin, Queen Elizabeth College, University of London

In view of the known effects of thiamine deficiency on the metabolism of the central nervous system, it is of interest to determine whether there are also effects on behaviour. The design of experiments which might answer this question requires the consideration of several factors. First, since thiamine deficiency reduces food consumption, it is necessary to have two control groups of animals; one general control and one caloric control (i.e. pair-fed). Second, it must be possible to follow the degree of deficiency by, for example, the measurement of growth rates, as well as the presence of overt signs of motor disturbance. Third, the anorexia of thiamine deficiency makes it undesirable to use food deprivation to motivate deficient animals in experimental situations introduced to test possible changes in behaviour.

Although during the past 25 years several workers have recorded investigations in this field, none have adequately controlled all these variables. It is not surprising therefore that contradictory conclusions have been reached from such experiments. For this reason, we undertook the investigation to be described.

Three groups, each of seven rats, were used. The groups were (I) general control, i.e. unrestricted food intake with adequate thiamine; (2) thiamine-deficient; (3) caloric control, i.e. pair-fed with group (2) but with adequate thiamine. As soon as the growth rates of groups 2 and 3 became significantly less than that of group I, behaviour tests were begun. The tests were designed to assess emotionality, learning in a discrimination unit, and serial learning in a water maze.

It was found that thiamine deficiency, up to the time of onset of polyneuritis, produced no differences in behaviour under stress or in learning. On the other hand, the caloric control animals showed greater mobility under stress, learned the discrimination problem faster, and were less rigid in behaviour. These effects of hunger on behaviour are of interest in relation to present concepts of irrelevant drives in learning.

It is hoped to publish full details of these experiments in the Quarterly fournal of Experimental Psychology. 